\section{Randall B. Smith}

University of St. Thomas, Houston, Texas

RSmith@stthom.ed

ORCID: 0000-0003-4262-4279

DOI: http://dx.doi.org/10.12775/BPTh.2020.007

\section{Biblica}

et

Patristica

Thoruniensia

13 (2020) 2: 175-187

ISSN (print) 1689-5150

ISSN (online) 2450-7059

\title{
Thomas Aquinas and Irenaeus on the Divine and Natural Law
}

\begin{abstract}
Thomas's account of the natural law owes a large debt to Aristotle and other early Greek philosophers back to Heraclitus. This debt has long been known and discussed. Largely unrecognized, however, are the crucial influences of the early Greek Fathers of the Church who mediated this classical philosophical heritage to the Christian world. They were the first to set out the relationship between the natural law, the Old Law, and grace which would have a decisive influence on Aquinas's famous "treatise on law" in the Summa of Theology. In this paper, I analyze Thomas's mature work on the natural law in STh I-II, qq. 90-108 and show how the roots of this view can be traced to the earliest Church, especially in the writings of the second century bishop and martyr, St. Irenaeus of Lyons. Of special interest is how Irenaeus transformed the Greek-Aristotelian notion of physis and "natural law" within the context of his discussion of the goodness of creation and the Mosaic Law, contrary to the popular Gnostic views of his day.
\end{abstract}

Keywords: Thomas Aquinas; Ireneaus; natural law; divine law; Mosaic Law; Old Law; Adversus Haereses.

\section{A Common Narrative about the Natural Law: The Missing Historical Piece}

\footnotetext{
A common narrative about the natural law divides its development into - 1 three basic eras: first, its foundations among classical Greek and Roman authors; second, its development among schoolmen of the Middle Ages, most prominently Thomas Aquinas who, although credited with great philosophical insight, is sometimes said, as we will see, to have confused matters by introducing God and divine law into the picture; and third, its modern development beginning with writers such as Hugo Grotius (1583-1645) and Samuel Pufendorf (1632-1694) who, it is often said, began the process of disentangling the natural law from the troublesome theological context in which it had been enmeshed
} 
by Christian theologians in the Middle Ages. ${ }^{1}$ This modern attempt to articulate a theory of natural law based on reason alone, distinct not only from divine revelation but also from any metaphysical claims about nature or human nature, continues to the present day, as natural law theorists of one philosophical school or another have attempted to pit some version of the natural law against modernity's two most prominent moral theories, utilitarianism and Kantian deontology. ${ }^{2}$

Consider the following passage from a 2004 Fordham Law Review article by Lloyd Weinreb, Dane Professor of Law at Harvard Law School, who writes:

Cicero, not himself an original thinker, provided the phrase "natural law." Brought into contact with Christian belief in a personal, all-embracing God, the normative natural order of the Greeks became Divine Providence, in which human beings, able in some measure to provide for themselves, have a share. Thomas Aquinas, of course, brought that to fruition in his doctrine of natural law.... In this way, natural law preserved the crucial elements of the Greek physis. It was real, and it was normative. Thereafter, aside from Christian theology, although the tradition of natural law continued, it lost that duality, which the intellectual separation of "is" and "ought" made impossible outside of "religion." In jurisprudence, natural law became one kind of moral theory, the distinctive quality of which was that it was said to be true, even self-evidently true. ${ }^{3}$

1 It is not generally recognized that the claim is not quite true of Grotius, but the process of separating the natural law from divine revelation was well on its way by the time Pufendorf wrote De jure naturae et gentium (1672) and De officio hominis et civis juxta legem naturalem libri duo (1673). See for example, the introduction by James Tully in Pufendorf: On the Duty of Man and Citizen According to Natural Law, tr. Michael Silverthorne, Cambridge Texts in the History of Political Thought (Cambridge: Cambridge University Press, 1991), xxii: "Pufendorf demarcates the study and practice of natural law from civil jurisprudence and the institution of divine law on one side and from moral theology and divine law on the other." For the later development of Christian natural law doctrine, see Matthew Levering, Biblical Natural Law (Oxford: Oxford University Press, 2008), which examines Aquinas but also treats the fate of the natural law doctrine in mainstream modern philosophy from Descartes to Nietzsche.

2 The attempt to reconcile utilitarian or consequentialist ethics with the natural law was most prominent in the work of proportionalists such as Peter Knauer, Josef Fuchs, Richard McCormick, and Louis Janssens. The attempt to reconcile deontological ethics with the natural law is associated most prominently with the "new natural law" theories of Germain Grizez and John Finnis.

3 Lloyd Weinreb, "A Secular Theory of Natural Law," Fordham Law Review, vol. 27, issue 6 (2004): 2289-90. Prof. Weinreb is simply setting forth in this passage what I take to be the common narrative in society today. 
Note the key moments in this account: the ancients, culminating in Cicero; then Aquinas; and finally the moderns. A crucial element missing from this common secular history of the natural law is the fundamental role played by Philo of Alexandria and the early Greek fathers who mediated the classical Greco-Roman natural law tradition to later generations. ${ }^{4}$

What distinguishes the modern accounts of the natural law from their earlier counterparts, suggests Prof. Weinreb, is that, "Reality, or nature, and especially the interconnectedness of the right and the real" was no longer relevant. Rather, "Puzzlement about humankind's place in nature was refashioned as a question of the relationship between the individual and the state, to which natural law in various guises, adapted to fit the theory at hand, provided an answer." ${ }^{5}$ This change is worth noting. In addition to the modern tendency to secularize accounts of the natural law, the natural law has also become less a moral and theological question about the human person's relation to God, nature, and others and more often in modernity a political or juridical issue about the individual's relation to the state and the proper limits of state power. These two developments are not unrelated, and both have had distinct influences on contemporary theories of natural law. I do not wish to claim that such modern approaches have not been helpful, but there also has perhaps been a narrowing of scholarly perspective that an engagement with the tradition would help us address.

\section{The Missing Texts on the Old and New Law}

A related textual problem involves the modern habit of separating questions 90 through 97 of the prima secundae of Thomas's Summa and publishing them separately under the title "The Treatise on Law" apart from the subsequent questions on the Old Law, New Law, and grace. An examination of medieval summae contemporaneous with Aquinas's would reveal, however, that nearly all of them began with a relatively brief set of questions on the different kinds of law, after which there was a long treatise on the Old Law, culminating in a discussion of divine grace - which is precisely the structure we find in Thomas's Summa. Questions 90 through 97 provide a relatively brief discussion of the different kinds of law, which is followed in questions 98 through 104, with an extended discussion (in some of the longest articles in the Summa) of the Old Law, and in questions 105-108 of the New Law, all of which concludes in ques-

\footnotetext{
4 See, for example, Philo, On Abraham, ch. 1; On the Creation of the World, ch. 1.

5 Weinreb, "A Secular Theory," 2290.
} 
tions 109 through 114 with a discussion of grace. When we consider the structure of these questions in Thomas's Summa in light of other contemporaneous summae of the period, we are drawn to the conclusion that what really animated the hearts and minds of the thinkers in the thirteenth century was not just the natural law per se as a distinctive moral theory, but how an understanding of the relationship between natural law, the Old Law, and grace could be mutually enlightening. ${ }^{6}$

We learn in these later articles on the Old Law, for example, that, according to Aquinas, God provided an authoritative revelation of the natural law in the moral precepts of the Old Law, which he distinguishes from the ceremonial and judicial precepts. Of the former, he says:

But the moral precepts derive their efficacy from the very dictate of natural reason, even if they were never included in the Law. Now of these there are three grades: for some are most certain, and so evident as to need no promulgation; such as the commandments of the love of God and our neighbor, and others like these... which are, as it were, the ends of the commandments; wherefore no man can have an erroneous judgment about them. Some precepts are more detailed, the reason of which even an uneducated man can easily grasp; and yet they need to be promulgated, because human judgment, in a few instances, happens to be led astray concerning them: these are the precepts of the decalogue. Again, there are some precepts the reason of which is not so evident to everyone, but only the wise; these are moral precepts added to the decalogue, and given to the people by God through Moses and Aaron. ${ }^{7}$

On this account, the "two first and common precepts of the natural law which are per se nota to human reason" are not "do good and avoid evil," but love God and love your neighbor as yourself, which, as Christ taught, "contain the whole of the law and the prophets. From these two precepts can be derived as "conclusions from common principles" the Ten Commandments of the Decalogue, and from these ten, the other moral precepts of the Old Law, such as the prohibitions against idolatry, fornication, various kinds of theft (such as

6 On the thirteen century interest in the Old Law, see Beryl Smalley, "William of Auvergne, John of La Rochelle, and St. Thomas Aquinas on the Old Law," in St. Thomas Aquinas, 1274-1974: Commemorative Studies (Toronto: P.I.M.S., 1974), 2:11-72.

7 ST I-II, q. 100, art. 11. Throughout I will be quoting from the translation by the Fathers of the English Dominican Province (Benziger Bros., 1947). For more on this topic, see my article "What the Old Law reveals about the Natural Law According to Thomas Aquinas," The Thomist, vol. 75, no. 1 (January 2011): 95-139. 
failure to pay a working man his wages), and various ways of bearing false witness, such as slander and gossip. ${ }^{8}$

Now the divine law is twofold, says Thomas: it consists of the Old Law and the New Law. ${ }^{9}$ Thus as Thomas says in the preface to q. 90 , after discussing how God "instructs us by means of His law," he will also describe how God "assists us by means of His grace." Hence we need the Old Law to teach us what we could and should know about the natural law, but don't because of the damage to our nature due to the Fall, and we need the New Law to fulfill its precepts with love. ${ }^{10}$

\section{Divine Law and Natural Law: A Confusion or Clarification?}

Fans of Thomistic natural law who prefer the modern secular approach are not always pleased to be told that Aquinas says we cannot fulfill the natural law without the help of grace.

In a similar secularist spirit, Michael Crowe, author of The Changing Profile of the Natural Law, criticizes Aquinas for perpetuating what Crowe considers to be the "regrettable confusion" between the natural law and the divine law introduced by Gratian who defined the natural law as "that which is contained in the law and the Gospel." 11 But in those often-unread questions on the Old Law and New Law, Thomas claims that God revealed the basic precepts of the

8 ST I-II, q. 100, a. 3, ad 1: "illa duo praecepta sunt prima et communia praecepta legis naturae, quae sunt per se nota rationi humanae, vel per naturam vel per fidem. Et ideo omnia praecepta Decalogi ad illa duo referuntur sicut conclusiones ad principia communia." For a more detailed description of the precepts of the third grade - those derived from the Ten Commandments - see also ST I-II, q. 100, art. 11. For an account of how the third grade of moral precepts of the Old Law can serve as a guide to prudence, see my article "How Faith Perfects Prudence: Thomas Aquinas on the Wisdom of the Old Law and the Gift of Counsel," in The Virtuous Life: Thomas Aquinas on the Theological Nature of Moral Virtues (Leuven: Peeters, 2017), 143-162.

9 ST I-II, q. 91, art. 5.

10 Cf. ST I-II, q. 98, art. 6 and ST I-II, qq. 106 and 107. See also my article "Natural Law and Grace: How Charity Perfects the Natural Law," in Faith, Hope, and Love: Thomas Aquinas on Living by the Theological Virtues, ed. H. Goris, et al. (Leuven: Peeters, 2015), 233-257.

11 See Michael Crowe, The Changing Profile of the Natural Law (The Hague: Martinus Nijhoff, 1977), 75, although here is quoting a passage from O. Lottin, Le droit naturel chez saint Thomas d’Aquin et ses prédécesseurs (Bruges: Beyaert, 1931), 11: “... Gratien ... soulignait une fâcheuse confusion entre le droit naturel et le droit divin.” But Crowe signals his agreement with this judgment throughout the book - as, for example, on p. 60 where he refers to "one of the most influential - and misleading - definitions of the natural law in the 
natural law in the Ten Commandments of the Decalogue and the two great commandments to love God and love your neighbor; after which He made possible its fulfillment with the gift of New Law, which is the grace of the Holy Spirit spreading charity abroad in our hearts. It is for this reason, therefore, that the natural law is, on Thomas's account, most properly described as "that which is contained in the law and the Gospel."12 And as we will see in a moment, rather than introducing confusion, Gratian and Thomas were simply passing on a centuries-old tradition from the earliest Church.

Indeed, far from "confusing" matters by adding theological considerations to the purely naturalistic reflections of the Greeks and Romans, I suggest that Christian theologians of the second century refined and clarified many of the confused notions about God or the gods and nature found in these earlier classical sources, and they did so for the most part in response to the challenges presented by (a) the Jewish monotheistic account of creation in Genesis 1 and (b) the Jewish-Christian, specifically Pauline, understanding of the pedagogical value of the Mosaic Law requiring for its fulfillment the reception in faith of God's grace.

This creative engagement of the classical Greek and Jewish traditions can be found in the works of dozens of Fathers of the early Church in both East and West. ${ }^{13}$ In the remainder of this essay, I hope to establish the importance of an early Church Father who, in a fascinating way, bridges this traditional divide between Greek East and Latin West: the great St. Irenaeus of Lyon. Born in 130 A.D. in Smyrna in the East, early enough to have heard the preaching of St. Polycarp, a disciple of John the Evangelist, he later became bishop of Lyon

Middle Ages, Gratian's assertion that the natural law is what is contained in the law and the gospel."

12 See ST I-II, q. 94, art. 4, ad 1. It is necessary to take into account Thomas's entire discussion of the relationship between the natural law, the Old Law, and the New Law, however, to understand why it is proper to say that the natural law is "what is contained in the Law and the Gospel." The phrase was "the keynote of one of the most influential - and misleading - definitions of the natural law in the Middle Ages...." (60)

13 In addition to the chapters in Irenaeus's Against Heresies discussed below (bk 4, chs. 12-18), see also Clement of Alexandria, Stromata, bk. 1, chs. 25-29 and the commentary on Romans 2 in Origen, Commentary on the Epistle to the Romans; John Chrysostom, Homilies on the Epistle to the Romans; Ambrosiaster, Commentaries on Romans; and Augustine, On the Spirit and the Letter, and The Free Choice of the Will, bk 1, chs. 5-16. For a nice summary of what Origen, Chrysostom, Ambrosiaster, and Augustine have to say about the natural law, see the essay by Matthew Levering in Andrew Emon, Matthew Levering, David Novack, Natural Law: A Jewish, Christian, and Islamic Trialogue (Oxford: Oxford University Press, 2014), 66-111. 
in the West. Though he himself wrote in Greek, ironically his works survive almost solely in Latin translations. ${ }^{14}$

\section{Irenaeus and the Natural Law: A Foretaste of the Thomistic Synthesis}

While many patristic discussions of the natural law are found in commentaries on the epistles of Paul, especially on those famous passages in Romans 2:14-15 about the Gentiles who, although they do not have the law, by nature do what the law requires, showing that what the Law requires is "written in their hearts," Irenaeus took up the topic in a series of articles in Book Four of Adversus Haereses where he argues against the Marcionite view that the God of the Old Testament was a tyrannical demi-urge not to be confused with the loving, "spiritual," "God the Father" of the New Testament. ${ }^{15}$ Irenaeus argued to the contrary that there is but one God, Creator of all things, who is also the one whom Christ called His Father. The importance of setting his discussion of the natural law in the context of creation will become apparent in due course.

The author of the law and the Gospel can be shown to be one and the same, argues Irenaeus, because in both the first and greatest commandment is to love God with one's whole heart and to love one's neighbor as oneself. Irenaeus describes these two as the "precepts of the perfect life" (consummatae vitae praecepta), stressing repeatedly that they are the same in each Testament ${ }^{16}$, and that

14 For an introduction to the life and work of Irenaeus, see Eric Francis Osborn, Irenaeus of Lyons (Cambridge: Cambridge University Press, 2001); Robert Grant, Irenaeus of Lyons (New York: Routledge, 1997). For an introduction to the text of the Adversus Haereses, see the introduction by Dominic J. Unger in St. Irenaeus of Lyons: Against the Heresies (Book 1), Ancient Christian Writers (Mahwah, NJ: Paulist Press, 1992).

15 For the context, see Adversus. Haereses. 4.12-16. Throughout, I have quoted the English translation by Alexander Roberts and William Rambaut in Ante-Nicene Fathers, Vol. 1. (Buffalo, NY: Christian Literature Publishing Co., 1885). The Latin text has been added. The Latin text was taken from W. Harvey, Sancti Irenaei Episcopi Lugdunensis Libros Quinque Adversus Haereses ... (Cantabrigiae: Typis Academicis, 1857).

16 Adv. Haer. 4.13.1: "As in the law, therefore, and in the Gospel [likewise], the first and greatest commandment is, to love the Lord God with the whole heart, and then there follows a commandment like to it, to love one's neighbour as one's self; the author of the law and the Gospel is shown to be one and the same. For the precepts of an absolutely perfect life (consummatae vitae praecepta) since they are the same in each Testament, have pointed out [to us] the same God, who certainly has promulgated particular laws adapted for each; but the more prominent and the greatest [commandments], without which salvation cannot [be attained], He has exhorted [us to observe] the same in both." 
"Christ did not abrogate the natural precepts of the Law (naturalia Legis), but rather fulfilled and extended them"17, setting mankind free to act not as slaves obeying a master, but with the love of sons. ${ }^{18}$

According to Irenaeus, "All the natural precepts (naturalia omnia praecepta) are common" to both Gentiles and Jews. "For to yield assent to God, and to follow His Word, and to love Him above all, and one's neighbour as one's self ... and to abstain from every evil deed, and all other things of a like nature which are common to both [covenants], do reveal one and the same God. But this is our Lord, the Word of God, who in the first instance certainly drew slaves to God, but afterwards He set those free who were subject to Him." 19

17 Adv. Haer. 4.13.1: "And that the Lord did not abrogate the natural [precepts] of the law, by which man is justified, which also those who were justified by faith, and who pleased God, did observe previous to the giving of the law, but that He extended and fulfilled them, is shown from His words. "For," He remarks, "it has been said to them of old time, Do not commit adultery. But I say unto you, that everyone who hath looked upon a woman to lust after her, hath committed adultery with her already in his heart ... But this which He did command - namely, not only to abstain from things forbidden by the law, but even from longing after them - is not contrary to [the law], as I have remarked, neither is it the utterance of one destroying the law, but of one fulfilling, extending, and affording greater scope to it."

18 Adv. Haer. 4.13.2: "For the law, since it was laid down for those in bondage, used to instruct the soul by means of those corporeal objects which were of an external nature, drawing it, as by a bond, to obey its commandments, that man might learn to serve God. But the Word set free the soul, and taught that through it the body should be willingly purified. Which having been accomplished, it followed as of course, that the bonds of slavery should be removed, to which man had now become accustomed, and that he should follow God without fetters: moreover, that the laws of liberty should be extended, and subjection to the king increased, so that no one who is convened should appear unworthy to Him who set him free, but that the piety and obedience due to the Master of the household should be equally rendered both by servants and children; while the children possess greater confidence [than the servants], inasmuch as the working of liberty is greater and more glorious than that obedience which is rendered in [a state of] slavery."

19 Adv. Haer. 4.13.4: "Inasmuch, then, as all natural precepts (naturalia omnia praecepta) are common to us and to them [the Jews], they had in them indeed the beginning and origin; but in us they have received growth and completion. For to yield assent to God, and to follow His Word, and to love Him above all, and one's neighbour as one's self (now man is neighbour to man), and to abstain from every evil deed, and all other things of a like nature which are common to both [covenants], do reveal one and the same God. But this is our Lord, the Word of God, who in the first instance certainly drew slaves to God, but afterwards He set those free who were subject to Him, as He does Himself declare to His disciples: "I will not now call you servants, for the servant knoweth not what his lord doeth; but I have called you friends, for all things which I have heard from My Father I have made known." For in that which He says, "I will not now call you servants," He indicates in the 
Christ has, says Irenaeus, "increased and widened those laws which are natural and noble and common to all (quae autem naturalia et liberalia et communia omnium), granting to men largely and without grudging, by means of adoption, to know God the Father, and to love Him with the whole heart, and to follow His word unswervingly, while they abstain not only from evil deeds, but even from the desire after them," for "sons should have more veneration than slaves, and greater love for their father." 20

There are repeated references in Irenaeus's text to the laws which are "natural, noble, and common to all," which Irenaeus identifies with "love God" and "love your neighbor as yourself," just as Thomas centuries later will refer to them as "first and common" (prima et communia). ${ }^{21}$ Note also Irenaeus's repeated insistence that these "natural" laws have received their "growth and completion" in Christ's gift whereby we become adopted sons of the Father. This freedom born of love is something Thomas would say is achieved with the gift of the Holy Spirit in the New Law.

An obvious question, however, is why, if these moral commandments are "natural" and "common to all," the Old Testament written law was necessary? Thomas's reply is that the Law was the first part of God's twofold plan to redeem man from the damage introduced by the fall.

Hence it was fitting [says Thomas] that the Law should be given at such a time as would be appropriate for the overcoming of man's pride. For man was proud of two things, namely of knowledge and of power. He was proud of his knowledge, as though his natural reason could suffice him for salvation: and accordingly, in order that his pride might be overcome in this matter, man was left to the guidance of his reason without the help of a written law: and man was able to learn from experience that his reason was deficient, since about the time of Abraham man had fallen headlong into idolatry and the most shameful vices. Wherefore ... it was necessary for a written law to be given as a remedy for human ignorance ... But, after man had been instructed by the Law, his pride was convinced of his weakness, through his being unable to fulfil what he knew. ${ }^{22}$

most marked manner that it was Himself who did originally appoint for men that bondage with respect to God through the law, and then afterwards conferred upon them freedom."

20 Adv. Haer. 4.16.5: "But He has increased and widened those laws which are natural, and noble, and common to all, granting to men largely and without grudging, by means of adoption, to know God the Father, and to love Him with the whole heart, and to follow His word unswervingly, while they abstain not only from evil deeds, but even from the desire after them. But He has also increased the feeling of reverence; for sons should have more veneration than slaves, and greater love for their father."

21 See n. 8 above.

22 ST I-II, q. 98, art. 6. 
Thus the Law was given to man "as a help," says Thomas, when "the natural law began to be obscured on account of the exuberance of sin: for it was fitting that this help should be bestowed on men in an orderly manner, so that they might be led from imperfection to perfection; wherefore it was becoming that the Old Law should be given between the law of nature and the law of grace."23

That was Aquinas. Here, then, is Irenaeus, writing eleven centuries earlier: "God admonished men, that is, by the Decalogue, of what first, from the beginning He had implanted in them by natural precepts" (per naturalia praecepta). ${ }^{24}$ For since "the righteous fathers had the meaning of the Decalogue (virtutem decalogi) written in their hearts and souls" (conscriptam ... in cordibus et animabus suis), that is, they loved the God who made them, and did no injustice to their neighbor," there was no need for them to be cautioned by "prohibitory mandates" (correptoriis literis), "because they had the righteousness of the law in themselves. But when this righteousness and love to God had passed into oblivion ... God did ... because of His great goodwill to men, reveal Himself by a voice, and led the people with power out of Egypt,... And it enjoined love to God, and taught just dealing towards our neighbour, that we should neither be unjust nor unworthy of God, who prepares man for His friendship through the medium of the Decalogue, and likewise for agreement with his neighbour matters which did certainly profit man himself; for God stood in no need of anything from man."25

23 Ibid.

24 Adv. Haer. 4.15.1: "For God at the first, indeed, warning them by means of natural precepts (per naturalia praecepta), which from the beginning He had implanted in mankind, that is, by means of the Decalogue (which, if any one does not observe, he has no salvation)...."

25 Adv. Haer. 4.16.3: "But the righteous fathers had the meaning of the Decalogue written in their hearts and souls, that is, they loved the God who made them, and did no injury to their neighbour. There was therefore no occasion that they should be cautioned by prohibitory mandates (correptoriis literis), because they had the righteousness of the law in themselves. But when this righteousness and love to God had passed into oblivion, and became extinct in Egypt, God did necessarily, because of His great goodwill to men, reveal Himself by a voice, and led the people with power out of Egypt, in order that man might again become the disciple and follower of God .... And it enjoined love to God, and taught just dealing towards our neighbour, that we should neither be unjust nor unworthy of God, who prepares man for His friendship through the medium of the Decalogue, and likewise for agreement with his neigbbour,-matters which did certainly profit man himself; God, however, standing in no need of anything from man." 


\section{The Eucharist: Redemption of the Created Order, Food for the Moral Life}

Irenaeus makes the point repeatedly that God needs nothing from man and so does not demand sacrifices in the manner of the ancient gods. "For God does not need our possessions," he tells his reader; rather "we make offerings to Him, not as though He stood in need of it, but rendering thanks for His gift, and thus sanctifying what has been created." ${ }^{26}$ Note how Irenaeus has turned the ancient idea of divine sacrifice on its head. It is not man who sacrifices to God, but God who sacrifices for man. And the ultimate sign of this marvelous exchange is the Eucharist, whereby Christ tells His disciples to offer back to God the fruits of God's own creation, bread and wine, not because God needs them or our worship, but so that we might be "neither unfruitful nor ungrateful," offering these created things and ourselves "to be transformed into Christ's body, which the Church receiving [this] from the apostles, offers to God throughout all the world." 27

Irenaeus's concern to refute the Marcioniates and show that the God of the Old Testament and the God of the New are one and the same culminated, as we have seen, in an incarnational, as opposed to a merely representational, understanding of the Eucharist. The order of learning, however, was likely the reverse. Having the Eucharist at the center of his ecclesial life and practice undoubtedly served to remind Irenaeus constantly of the goodness of God's material creation and its role as an instrument and embodiment of God's love, a truth revealed most fully in the Word becoming flesh and in the bread and wine becoming the body and blood of Christ.

26 Adv. Haer. 4.18.6.

27 Adv Haer. 4.17.5: "Again, giving directions to His disciples to offer to God the firstfruits of His own, created things-not as if He stood in need of them, but that they might be themselves neither unfruitful nor ungrateful-He took that created thing, bread, and gave thanks, and said, "This is My body." And the cup likewise, which is part of that creation to which we belong, He confessed to be His blood, and taught the new oblation of the new covenant; which the Church receiving from the apostles, offers to God throughout all the world, to Him who gives us as the means of subsistence the first-fruits of His own gifts in the New Testament....” 


\section{The Marriage of Athens and Jerusalem: Hellenic Natural Law and Old Testament Creation and the Mosaic Law}

Irenaeus was able to interpret the Ten Commandments in terms of the classical Hellenic natural law tradition because he understood these commandments to be expressions of the will and wisdom of the one God, who created us, body and soul, along with everything else in the universe, the same God whose loving will to redeem us from our sin was revealed most fully in the sacrifice of His Son. We can trust the God of the first covenant, the God of creation and the law, the Creator of Nature, because of the infinite love He revealed by ratifying the New Covenant with His own blood, helping mankind fulfill the law and perfect their natures with the gift of His own Spirit.

So too, by interpreting the written commandments of the Mosaic Law in light of the classical natural law tradition, early Greek fathers such as Irenaeus could clarify for the Gentile world why the commandments of the Decalogue should be thought of neither (a) as demands from a deity such as Zeus or Jove whose rule, patterned on human kingship, was based on power and his own self-regarding will; or (b) as the necessary requirements of an order of nature or of fate to which God, like us, owed his obedience. Rather these commandments were now to be understood as moral prescriptions grounded in the very nature of what it means to be truly human.

Far from introducing confusion into the classical accounts of the natural law, therefore, Greek Fathers such as Irenaeus refined and clarified many of the confused notions about god or the gods and Nature and about why and in what ways Nature can or should serve as a morally authoritative standard of human conduct found in earlier classical thinkers. Irenaeus and other Greek Fathers responded to this intellectual challenge with a more refined understanding of creation and our specific human nature as God created us, a nature he believed was revealed most fully in Christ and governed most properly by the love of God and neighbor and the Ten Commandments.

By integrating the classical natural law tradition with the Jewish-Christian account of the written Mosaic Law, Irenaeus bequeathed to future generations a fertile intellectual heritage from which Thomas, in his own account of the law, in the Summa would produce much fruit. ${ }^{28}$

28 There is little doubt, however, that this tradition was mediated to Aquinas primarily through the works of Augustine. I am not arguing here for a direct influence, merely noting that the relationship between the natural law and the Mosaic law we find in Aquinas was already present in the second century of the Christian era. 


\section{Bibliography}

Crowe, Michael. The Changing Profile of the Natural Law. The Hague: Martinus Nijhoff, 1977.

Grant, Robert. Irenaeus of Lyons. New York: Routledge, 1997.

Irenaeus. Against Heresies. In Ante-Nicene Fathers, Vol. 1. Translated by Alexander Roberts and William Rambaut. Buffalo, NY: Christian Literature Publishing Co., 1885.

Irenaeus. Sancti Irenaei Episcopi Lugdunensis Libros Quinque Adversus Haereses ... Cantabrigiae: Typis Academicis, 1857.

Levering, Matthew, David Novack, and Andrew Emon. Natural Law: A Jewish, Christian, and Islamic Trialogue. Oxford: Oxford University Press, 2014. 66-111.

Levering, Matthew. Biblical Natural Law. Oxford: Oxford University Press, 2008.

Lottin, Odon. Le droit naturel chez saint Thomas d'Aquin et ses prédécesseurs. Bruges: Beyaert, 1931.

Osborn, Eric Francis. Irenaeus of Lyons. Cambridge: Cambridge University Press, 2001.

Philo. On Abraham. On Joseph. On Moses. Translated by F. H. Colson. Loeb Classical Library 289. Cambridge, MA: Harvard University Press, 1935.

Philo. On the Creation. Allegorical Interpretation of Genesis 2 and 3. Translated by F. H. Colson, G. H. Whitaker. Loeb Classical Library 226. Cambridge, MA: Harvard University Press, 1929.

Pufendorf, Samuel von. Pufendorf: On the Duty of Man and Citizen According to Natural Law. Trans. Michael Silverthorne. Cambridge Texts in the History of Political Thought. Cambridge: Cambridge University Press, 1991.

Roszak, Piotr, and Jörgen Vijgen. Reading Sacred Scripture with Thomas Aquinas: Hermeneutical Tools, Theological Questions and New Perspectives. Turnhout: Brepols, 2015.

Smalley, Beryl. "William of Auvergne, John of La Rochelle, and St. Thomas Aquinas on the Old Law." In St. Thomas Aquinas, 1274-1974: Commemorative Studies. Toronto: P.I.M.S., 1974. 2: 11-72.

Smith, Randall. "How Faith Perfects Prudence: Thomas Aquinas on the Wisdom of the Old Law and the Gift of Counsel." In The Virtuous Life: Thomas Aquinas on the Theological Nature of Moral Virtues. Leuven: Peeters, 2017. 143-162.

Smith, Randall. "What the Old Law reveals about the Natural Law According to Thomas Aquinas." The Thomist, vol. 75, no. 1 (January 2011): 95-139.

Smith, Randall. "Natural Law and Grace: How Charity Perfects the Natural Law." In Faith, Hope, and Love: Thomas Aquinas on Living by the Theological Virtues. Edited by H. Goris, et al. Leuven: Peeters, 2015. 233-257.

Thomas Aquinas, Summa Theologica. Translated by the Fathers of the English Dominican Province. New York: Benziger Bros., 1947.

Unger, Dominic J. Introduction in St. Irenaeus of Lyons: Against the Heresies (Book 1). Ancient Christian Writers. Mahwah, NJ: Paulist Press, 1992.

Weinreb, Lloyd. "A Secular Theory of Natural Law." Fordham Law Review, vol. 27, issue 6 (2004): 2289-2290. 